Article

\title{
Porphyra-334 Isolated from the Marine Algae Bangia atropurpurea: Conformational Performance for Energy Conversion
}

\section{Li-Fan Chuang ${ }^{1, *}$, Hong-Nong Chou ${ }^{1}$ and Ping-Jyun Sung ${ }^{2}$}

1 Institute of Fisheries Science, National Taiwan University, No. 1, Sec. 4, Roosevelt Rd., Da-An district, Taipei 106, Taiwan; E-Mail: unijohn@ntu.edu.tw

2 Institute of Marine Biotechnology, National Dong Hwa University, Pingtung 944, Taiwan; E-Mail: pjsung@nmmba.gov.tw

* Author to whom correspondence should be addressed; E-Mail: d96b45003@ntu.edu.tw; Tel.: +886-2-3366-2878; Fax: +886-2-2362-9919.

Received: 25 April 2014; in revised form: 30 July 2014 / Accepted: 25 August 2014 /

Published: 3 September 2014

\begin{abstract}
Prophyra-334 (p-334) may play a role of energy transfer under an uncertain mechanism, and we speculate the possible model. Via 1D and 2D NMR experiments, it was simulated the correlation between dissociation and conformation of p-334. Intramolecular interactions were observed based on a series of changes in the $1 \mathrm{H}$ and $13 \mathrm{C}$ chemical shifts. Nuclear Overhauser effect spectroscopy experiments and molecular models in various $\mathrm{pD}$ conditions indicated the p-334 molecular dissociation process status. In addition, we also used Chem3D software to find the most possible molecular conformation. The relationship between the structural status and energy conversion is explained. Those are the primary results. More researches on it are highly expected in the future.
\end{abstract}

Keywords: porphyra-334; $\mathrm{p} K_{\mathrm{a}}$; titration; conformation

\section{Introduction}

Porphyra-334 (Figure 1; p-334; $\lambda_{\max }=334 \mathrm{~nm} ; \varepsilon=42,300 \mathrm{M}^{-1} \cdot \mathrm{cm}^{-1}$ ) belongs to the class of mycosporine-like amino acids (MAAs) that is a common constituent of algae and aquatic organisms [1]. It has been observed in high concentrations in some algae, particularly Porphyra spp. and Bangia atropurpurea [2,3]. This compound has been proved to be an activator of cell proliferation [4] and an 
antioxidant [5]; moreover, it is a UV protector [6] and is currently being explored regarding potential use in the cosmetics industry as a sunscreen agent [7]. In addition, p-334 can absorb light energy, and more than $90 \%$ of the excitation energy can be transferred to heat, which is released to the surrounding molecules; thus, p-334 can be considered an energy-converting substance [8,9].

Figure 1. The molecular structure of porphyra-334.

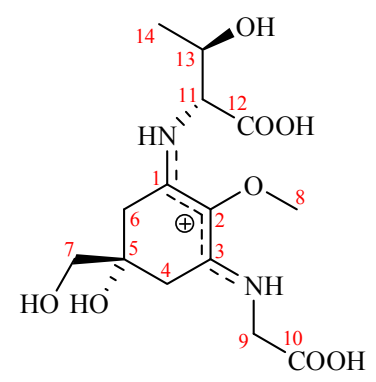

In previous studies, $\mathrm{p}-334$ was stable in a medium after $25 \mathrm{~h}$ in environments in which the $\mathrm{pH}$ was between 2 and 11 and the temperature was below $40{ }^{\circ} \mathrm{C}$ [10]. These results suggested that $\mathrm{p}-334$ is stable and can be passed safely through the stomach and accumulated in organisms. P-334 is monomeric in a $\mathrm{D}_{2} \mathrm{O}$ solution, and it has been suggested to be the imino N-protonated form of p-334 based on the results of $a b$ initio ${ }^{13} \mathrm{C}-\mathrm{NMR}$ chemical shift calculation and NMR Predict software [11]. These results indicate that p-334 should carry a positive charge in a solution and that energy conversion involves electron transfer and the structural status. However, this zwitterion compound may exhibit a negative charge or no charge in organisms, prompting us to study whether one or two protons are ionized from these carboxylic acid groups and to clarify the correlation between the structure and energy conversion. This experiment was conducted to determine $\mathrm{p} K_{\mathrm{a}}$ values by using various NMR chemical shifts. In addition, p-334 is an efficient proton sponge that is expected to have a relationship with intramolecular interactions [11]. The structural conformations of the ionic and neutral forms were determined using nuclear Overhauser effect spectroscopy (NOESY). Furthermore, the p-334 effect relative to cell proliferation is addressed.

\section{Results and Discussion}

According to the progress of extract filtration, p-334 was easily extracted from the algae B. atropurpurea, indicating that MAAs exist between the cell wall and the membrane. This is the first time this observation has been reported, and it may be related to the energy conversion of UV light into heat considered the growth environment. This topic will be studied further in the future. After p-334 was eluted from the ion exchange column, the $\mathrm{pH}$ of the eluent was observed to be approximately 3.0; this value is close to the measured $\mathrm{p} K_{\mathrm{a}}$ value from NMR.

The results of titrations indicated that the hydrogen molecules around two of the carboxylic acid groups were affected, and chemical shifts changed before pD 4 (Figure 2). However, we calculated equivalents and demonstrated that only one proton ionised from a carboxylic acid. The $\mathrm{p} K_{\mathrm{a}}$ was evaluated according to the equation $\mathrm{p} K_{\mathrm{a}}=0.929\left\{\mathrm{pD}+\log \left(\left(\delta-\delta_{\mathrm{n}}\right) /\left(\delta_{\mathrm{i}}-\delta\right)\right)\right\}+0.42$, in which $\delta$ is the chemical shift at a given $\mathrm{pD}$, and $\delta_{\mathrm{n}}$ and $\delta_{\mathrm{i}}$ indicate the intrinsic chemical shift values for the nonionic and ionic species, respectively [12,13]. The values calculated from Figure 2a were $2.95 \pm 0.09$ (H-9), 
$2.89 \pm 0.10(\mathrm{H}-10), 2.91 \pm 0.14(\mathrm{H}-11)$, and $2.96 \pm 0.11(\mathrm{H}-12)$, and the average was $2.92 \pm 0.11$. Figure $2 \mathrm{~b}$ provides values of $2.94 \pm 0.11\left(\mathrm{C}_{(1)}\right), 2.96 \pm 0.12\left(\mathrm{C}_{(2)}\right)$, and $2.85 \pm 0.12\left(\mathrm{C}_{(3)}\right)$ for the $\mathrm{p} K_{\mathrm{a}}$, and the average was $2.92 \pm 0.12$. This is the same $\mathrm{p} K_{\mathrm{a}}$ calculated based on ${ }^{1} \mathrm{H}$ and ${ }^{13} \mathrm{C}$ NMR chemical shifts, indicating that the structure contained intramolecular interactions and that change occurred upon proton ionization.

Figure 2. $\mathrm{pD}$ dependence of the (a) ${ }^{1} \mathrm{H}$ chemical shift and (b) ${ }^{13} \mathrm{C}$ chemical shift of p-334.

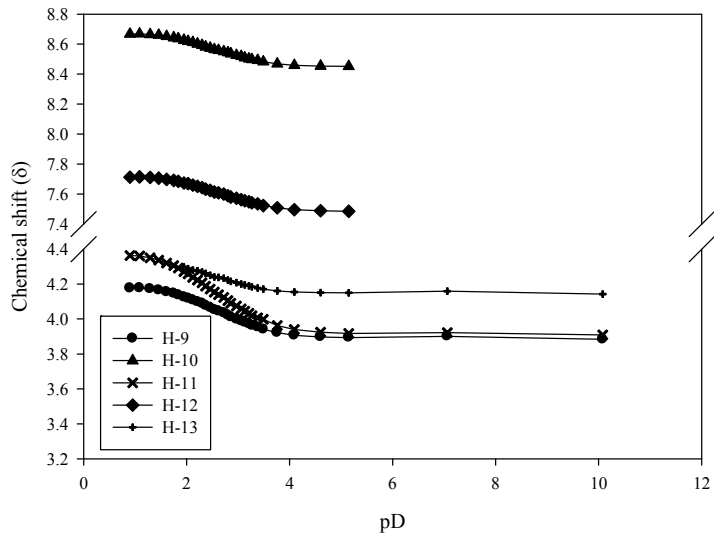

(a)

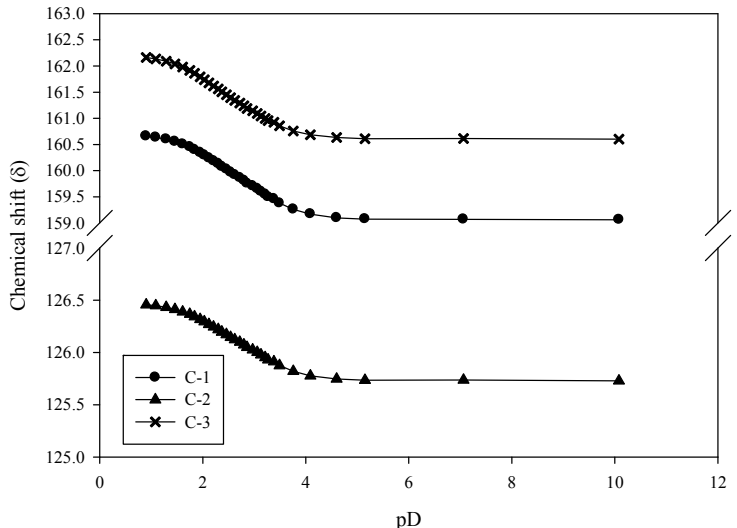

(b)

The NOESY experiments revealed that p-334 exhibited various conformations in several $\mathrm{pD}$ conditions (Figure 3). At pD 1.0, NOESY correlations between $\mathrm{H}-11$ and $\mathrm{H}^{\alpha}-4, \mathrm{H}^{\alpha}-6$, and $\mathrm{H}_{2}-9$, as well as between $\mathrm{H}-13$ and $\mathrm{H}_{2}-9$ were observed. However, at pD 2.0, NOE correlations were observed between $\mathrm{H}_{3}-14$ and $\mathrm{H}_{3}-8$, and between $\mathrm{H}-11$ and both $\mathrm{H}^{\alpha}-4$ and $\mathrm{H}_{2}-6$. At $\mathrm{pD} 3.5, \mathrm{H}-11$ was observed to engage in NOE interactions with only $\mathrm{H}^{\alpha}-4$ and $\mathrm{H}^{\alpha}-6$, and $\mathrm{H}_{3}-14$ interacted with $\mathrm{H}_{3}-8$. The intramolecular interactions increased the stability of the conformation [11]; for example, at $\mathrm{pD}$ 1.0, $\mathrm{C}_{(1)} \mathrm{NH}$ interacted with $\mathrm{C}_{(2)} \mathrm{O}$ and $\mathrm{C}_{(13)} \mathrm{O}, \mathrm{H}-13$ interacted with $\mathrm{C}_{(2)} \mathrm{O}$, and $\mathrm{H}-11$ interacted with $\mathrm{C}_{(5)} \mathrm{O}$, preventing the $\mathrm{NH}$ of the threonine side chain from rotating freely. The $\mathrm{NH}$ of the glycine side chain also exhibited contact between $\mathrm{C}_{(3)} \mathrm{NH}$ to $\mathrm{C}_{(10)} \mathrm{O}$ and $\mathrm{C}_{(2)} \mathrm{O}$ (Table 1).

Figure 2a shows that the shifting distance of H-11 was two times greater than that of other types of hydrogen, suggesting that the change in electron density was two times greater than that of other types of hydrogen. Between pD 1.0 and pD 3.5, H-13 interacted with $\mathrm{C}_{(2)} \mathrm{O}$ initially, but then interacted with $\mathrm{C}_{(12)} \mathrm{O} . \mathrm{H}_{3}-14$ exhibited a reversed process; therefore, it maintained the same electron density (Table 1). However, the hydrogen of $\mathrm{C}_{(13)} \mathrm{OH}$ interacted with $\mathrm{C}_{(12)} \mathrm{O}$, causing the electron densities of $\mathrm{H}-13$ and $\mathrm{H}-11$ to increase. In addition, hydrogen ionization from $\mathrm{C}_{(12)} \mathrm{OH}$ caused the electron density of $\mathrm{H}-11$ to increase twofold. Thus, the dissociated proton may have been located in the carboxylic acid group of the threonine side chain, and the hydrogen of $\mathrm{C}_{(13)} \mathrm{OH}$ may have interacted with $\mathrm{H}-12$, producing a hydrogen signal from ${ }^{1} \mathrm{H}-\mathrm{NMR}$. According to these findings, the hydrogen of $\mathrm{C}_{(10)} \mathrm{OH}$ may have interacted with $\mathrm{C}_{(2)} \mathrm{O}$, engendering the increased electron densities of $\mathrm{H}-9$ and H-10 simultaneously. 
Figure 3. Selective NOESY correlations of p-334 and the possible process of conformational change as shown by molecular models under different $\mathrm{pD}$ conditions. The dashed lines in the chemical structures of the scheme represent possible paths of electron resonance. (a) p-334 dissolved in $\mathrm{D}_{2} \mathrm{O}$ and titrated by $\mathrm{DCl}(\mathrm{pD} 1.0)$; (b) also titrated by $\mathrm{DCl}(\mathrm{pD} 2.0$ ); (c) no treatment (pD 3.5).

(a)
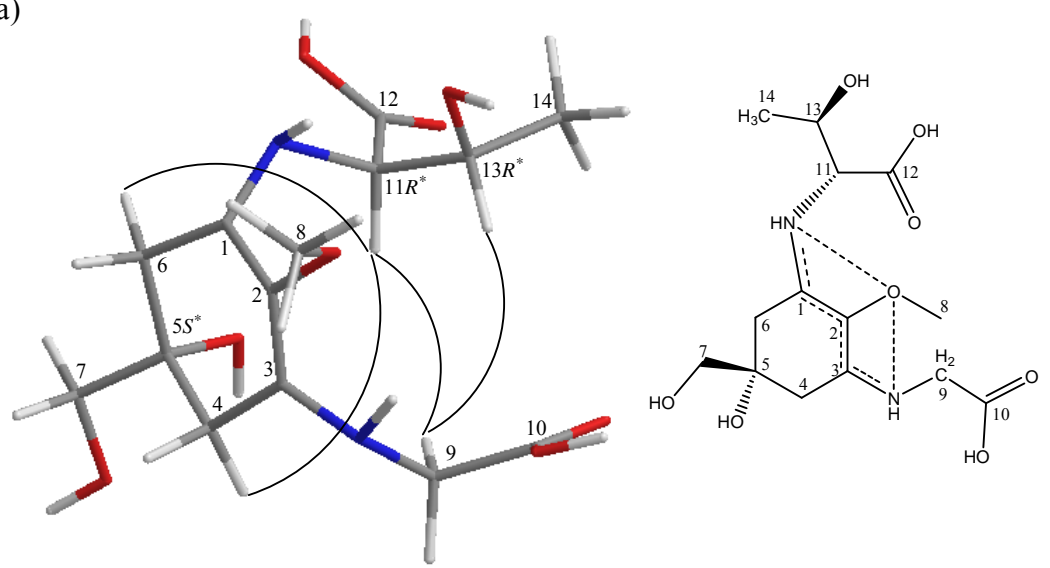

(b)
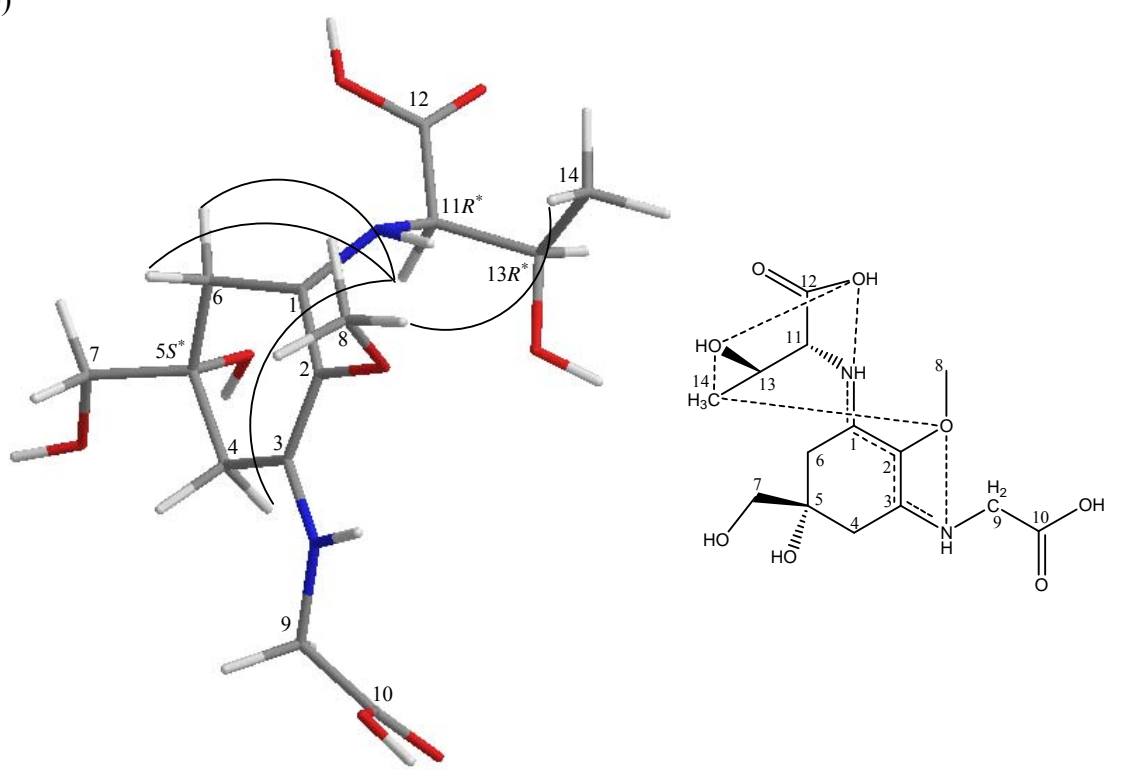

(c)

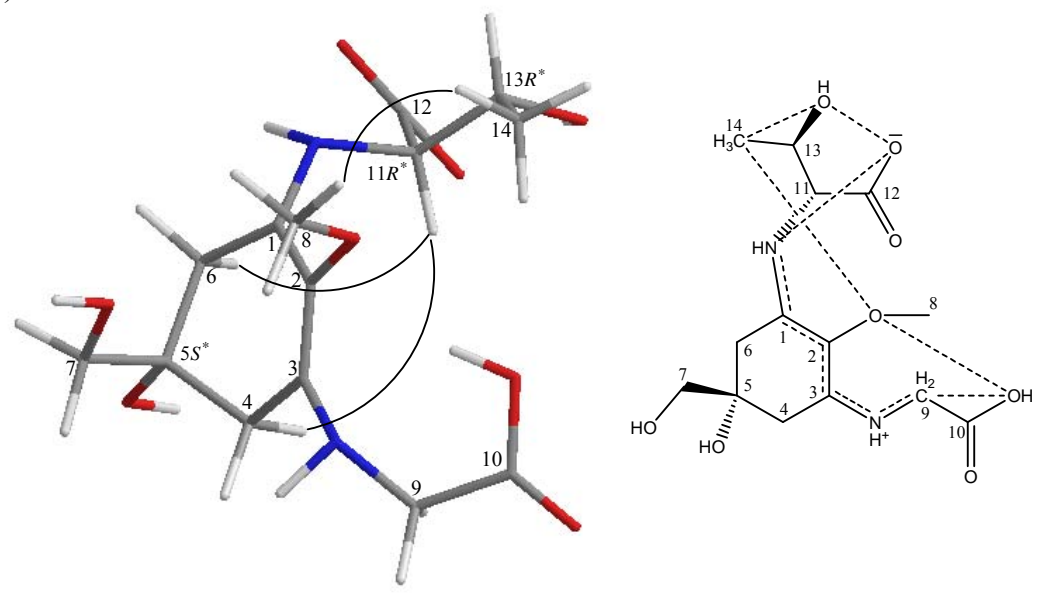


Table 1. The calculated distances below $3.00 \AA$ between selected protons and oxygens by molecular models.

\begin{tabular}{|c|c|c|c|c|c|c|}
\hline \multirow{2}{*}{$\begin{array}{c}\text { pD } \\
\text { Proton }\end{array}$} & \multicolumn{2}{|c|}{1.0} & \multicolumn{2}{|c|}{2.0} & \multicolumn{2}{|c|}{3.5} \\
\hline & Oxygen & $(\AA \AA)$ & Oxygen & $(\AA)$ & Oxygen & $(\AA \AA)$ \\
\hline \multirow{2}{*}{$\mathrm{C}_{(1)} \mathrm{N}-\mathrm{H}^{\mathrm{a}}$} & $\mathrm{C}_{(2)} \mathrm{O}$ & 2.21 & $\mathrm{C}_{(2)} \mathrm{O}$ & 2.20 & $\mathrm{C}_{(12)} \mathrm{O}$ & 1.64 \\
\hline & $\mathrm{C}_{(13)} \mathrm{O}$ & 1.98 & $\mathrm{C}_{(13)} \mathrm{O}$ & 2.44 & - & - \\
\hline \multirow{2}{*}{$\mathrm{C}_{(3)} \mathrm{N}-\mathrm{H}^{\mathrm{b}}$} & $\mathrm{C}_{(2)} \mathrm{O}$ & 2.14 & $\mathrm{C}_{(2)} \mathrm{O}$ & 2.30 & - & - \\
\hline & $\mathrm{C}_{(10)} \mathrm{O}$ & 2.09 & $\mathrm{C}_{(10)} \mathrm{O}$ & 2.58 & - & - \\
\hline $\mathrm{C}_{(5)} \mathrm{O}-\mathrm{H}$ & $\mathrm{C}_{(7)} \mathrm{O}$ & 2.15 & $\mathrm{C}_{(7)} \mathrm{O}$ & 2.11 & - & - \\
\hline $\mathrm{H}_{2}-9$ & $\mathrm{C}_{(10)} \mathrm{O}$ & 2.61 & $\mathrm{C}_{(10)} \mathrm{O}$ & 2.58 & $\mathrm{C}_{(10)} \mathrm{O}$ & 2.60 \\
\hline $\mathrm{C}_{(10)} \mathrm{O}-\mathrm{H}$ & - & - & - & - & $\mathrm{C}_{(2)} \mathrm{O}$ & 2.09 \\
\hline \multirow{2}{*}{$\mathrm{H}-11$} & $\mathrm{C}_{(5)} \mathrm{O}$ & 2.50 & $\mathrm{C}_{(5)} \mathrm{O}$ & 2.45 & $\mathrm{C}_{(12)} \mathrm{O}$ & 2.08 \\
\hline & $\mathrm{C}_{(12)} \mathrm{O}$ & 2.70 & $\mathrm{C}_{(13)} \mathrm{O}$ & 2.55 & $\mathrm{C}_{(13)} \mathrm{O}$ & 2.61 \\
\hline \multirow{2}{*}{$\mathrm{H}-13$} & $\mathrm{C}_{(2)} \mathrm{O}$ & 2.64 & $\mathrm{C}_{(12)} \mathrm{O}$ & 2.77 & $\mathrm{C}_{(12)} \mathrm{O}$ & 2.44 \\
\hline & $\mathrm{C}_{(13)} \mathrm{O}$ & 2.01 & $\mathrm{C}_{(13)} \mathrm{O}$ & 2.04 & $\mathrm{C}_{(13)} \mathrm{O}$ & 2.03 \\
\hline $\mathrm{C}_{(13)} \mathrm{O}-\mathrm{H}$ & - & - & - & - & $\mathrm{C}_{(12)} \mathrm{O}$ & 1.85 \\
\hline \multirow{2}{*}{$\mathrm{H}_{3}-14$} & $\mathrm{C}_{(12)} \mathrm{O}$ & 2.57 & $\mathrm{C}_{(13)} \mathrm{O}$ & 2.64 & $\mathrm{C}_{(2)} \mathrm{O}$ & 2.61 \\
\hline & $\mathrm{C}_{(13)} \mathrm{O}$ & 2.63 & - & - & $\mathrm{C}_{(13)} \mathrm{O}$ & 2.59 \\
\hline
\end{tabular}

${ }^{a}$ The NH group on the threonine side chain; ${ }^{\mathrm{b}}$ The NH group on the glycine side chain.

According to the results of these chemical shifts, $\mathrm{C}_{(3)}$ was determined to have a higher electron density than $\mathrm{C}_{(1)}$ and $\mathrm{C}_{(2)}$ do because $\mathrm{C}_{(2)} \mathrm{O}$ interacted with other types of hydrogen (Figure $2 \mathrm{~b}$ ). P-334 can be called a "proton sponge compound [11]", because it can form strong intramolecular interactions. At $\mathrm{pD} 1.0$, the cycles of the electronic orbitals were $\mathrm{C}_{(8)} \mathrm{H}_{3}-\mathrm{O} \ldots \mathrm{H}-\mathrm{N}-\mathrm{C}_{(1)} \ldots \mathrm{C}_{(2)}$ and $\mathrm{C}_{(8)} \mathrm{H}_{3}-\mathrm{O} \ldots \mathrm{H}-\mathrm{N}-\mathrm{C}_{(3)} \ldots \mathrm{C}_{(2)}$ (Figure 3a). However, at pD 2.0, some protons dissociated from $\mathrm{C}_{(12)} \mathrm{OH}$, resulting in an increase in the electron density of the threonine side chain and causing the electron density around $\mathrm{C}_{(12)}$ to increase. The balance connection between the threonine side chain and the glycine side chain were broken. The electron density increased, and the mutual repulsion increased, thus causing the electron orbitals and conformation of p-334 to change. The mode of connection becomes $\mathrm{C}_{(8)} \mathrm{H}_{3}-\mathrm{O} \ldots \mathrm{C}_{(14)} \mathrm{H}_{3} \ldots \mathrm{C}_{(13)} \mathrm{O}-\mathrm{H} \ldots \mathrm{C}_{(12)} \mathrm{O} \ldots \mathrm{H}-\mathrm{N}-\mathrm{C}_{(1)} \ldots \mathrm{C}_{(2)}$ and $\mathrm{C}_{(8)} \mathrm{H}_{3}-\mathrm{O} \ldots \mathrm{H}-\mathrm{N}-\mathrm{C}_{(3)} \ldots \mathrm{C}_{(2)}$ (Figure $3 b$ ). We predict that, as more protons dissociate at $\mathrm{pD} 3.5$, more $\mathrm{C}_{(1)} \mathrm{NH}$ interacts with $\mathrm{C}_{(12)} \mathrm{O}$, and the distance between $\mathrm{C}_{(1)} \mathrm{NH}$ and $\mathrm{C}_{(2)} \mathrm{O}$ increases. Finally, interactions may form a cycle of $\mathrm{C}_{(8)} \mathrm{H}_{3}-\mathrm{O} \ldots \mathrm{C}_{(14)} \mathrm{H}_{3} \ldots \mathrm{C}_{(13)} \mathrm{O}-\mathrm{H} \ldots \mathrm{C}_{(12)} \mathrm{O} \ldots \mathrm{H}-\mathrm{N}-\mathrm{C}_{(1)} \ldots \mathrm{C}_{(2)}$ and $\mathrm{C}_{(8)} \mathrm{H}_{3}-\mathrm{O} \ldots \mathrm{C}_{(10)} \mathrm{H}-\mathrm{O} \ldots \mathrm{C}_{(9)} \mathrm{H}_{2} \ldots \mathrm{H}-\mathrm{N}-$ $\mathrm{C}_{(3)} \ldots \mathrm{C}_{(2)}$ (Figure $3 \mathrm{c}$ ). The widely electronic orbitals improve the stability and increase the proton affinity of the structure. These results also indicated that the electron density of $\mathrm{C}_{(1)}$ to $\mathrm{C}_{(3)}$ increased (Figure 2b). Zhang et al. (2005) [10] reported that the maximal absorption of p-334 exhibited a hypsochromic shift below $\mathrm{pH} 3$. A hypsochromic shift on UV spectra indicates greater energy content; hence, we suggest that p-334 ionization is a key on energy transfer on-off.

Proton-coupled electron transfer (PCET) reactions are ubiquitous in energy conversion and storage reactions in biology [14]. The energy-conversion activity of P-334 might involve PCET reactions. The $\mathrm{NAD}(\mathrm{P}) / \mathrm{NAD}(\mathrm{P}) \mathrm{H}$ redox couple is a suitable model for explaining the role of $\mathrm{p}-334$ in energy-conversion reactions [15,16]. However, energy cannot always do the conversion. If the structural conformation of p-334 in Figure $3 c$ is the energy consumption status in organisms that will 
perform energy conversion, then the progress of $p-334$ ionization in Figure $3 b$ should have as the appearance energy threshold [17-19]. Hence, Figure 3a is the energy storage status. The involvement of p-334 ionization in protonic systems might relative in light-driven proton pumps [20-22], explaining why MAAs are present in halophilic cyanobacteria $[23,24]$ and fish eye tissues $[25,26]$.

MAAs are present in the organs of marine organisms such as green sea urchin before spawning (Strongylocentrotus droebachiensis) [27,28]. MAAs accumulate in the ovaries during gastrulation, and larvae still contain MAAs; however, in the next stage of larval growth, the MAAs concentration decrease. In another urchin (Sterechinus neumayeri), the ovaries exhibit high MAAs concentrations, but the testes do not [29]. The ovaries of various types of fish, such as cod and common dab, contain approximately $4 \mathrm{mg} \cdot \mathrm{g}^{-1}$ of mature eggs [30,31]. These observations support that MAAs act as energy-converting substances that facilitate cell proliferation and biological reproduction. The results of cell proliferation $(0.25 \mu \mathrm{M})$ of $3 \mathrm{~T} 3$ mouse fibroblast cells were accelerating growth by approximately $40 \%$, that similar as Oyamada et al. studies [4]. Although the mechanism remains unclear, we believe that it is related to the aforementioned features of MAAs. Further research is required to confirm these observations. More details are available in Supplementary Information.

\section{Experimental Section}

\subsection{Procedure for Purifying P-334}

B. atropurpurea was purchased from the market, and was identified by algal professional, Prof. Chou. The following protocol was used to purify p-334: Extract filtration: Two steps occurred at nearly the same time that the "go-through" way was used. The extracts were filtered and the concentration was calculated according to the Beer-Lambert law. Absorbance was detected using a UV-VIS spectrophotometer. The concentration of p-334 in extracts was approximately $0.1 \%$. Adsorption: The extraction was passed through an ion exchange chromatography column that contained $40 \mathrm{~g}$ of Dowex $50 \mathrm{~W}-\mathrm{X} 8$ (200-400 mesh) gels by using a peristaltic pump, and the column was washed with $\mathrm{H}_{2} \mathrm{O}$ and eluted with $0.5 \mathrm{~N} \mathrm{HCl}$. The purity of p-334 was at least $50 \%$. Eluate fractions containing p-334 were concentrated and dried. Purification: The p-334 was purified using a Cosmosil $140 \mathrm{C}_{18}$-OPN chromatography column and eluted using isocratic $0.04 \% \mathrm{AcOH} / \mathrm{H}_{2} \mathrm{O}$. According to high-performance liquid chromatography results [32], the purity was greater than $99 \%$.

\subsection{Properties of the P-334 Experiment}

pD studies: The sample concentration of $\mathrm{D}_{2} \mathrm{O}$ was approximately $0.37 \mathrm{M}$. A glass electrode was employed in adjusting the $\mathrm{pD}$ from $\mathrm{pD} 0.9$ to 3.4 by using diluted $\mathrm{DCl}$ and from $\mathrm{pD} 3.5$ to 10.1 by using diluted NaOD. All measurements were conducted at $25{ }^{\circ} \mathrm{C}$ with ${ }^{1} \mathrm{H}$ NMR $(400 \mathrm{MHz})$ and ${ }^{13} \mathrm{C}$ NMR (100 MHz) spectra which 32 and 256 scans, respectively. The ${ }^{1} \mathrm{H}$ NMR chemical shifts were determined based on the signal of HOD peak. Computer processing was performed using the vnmr Varian software. Structural conformation studies: $\mathrm{P}-334$ prepared at $0.05 \mathrm{M}$ in $\mathrm{D}_{2} \mathrm{O}$ was used in the 2D NOESY experiments, in which the $\mathrm{pD}$ was adjusted to 1.0 and 2.0 were detected using a $400-\mathrm{MHz}$ NMR spectrometer which recorded 32 scans at $25{ }^{\circ} \mathrm{C}$. Proliferation assay: This assay was conducted according to the procedure described by Oyamada et al. [4]. Molecular models: These models were 
applied to calculate the minimal energy by using the Chem3D Ultra 9.0 software (PerkinElmer, Waltham, MA, USA).

\section{Conclusions}

According to the data, proton ionization from the carboxylic acid group of the threonine side chain and the structural conformations of $\mathrm{p}-334$ in three $\mathrm{pD}$ conditions revealed the progress of $\mathrm{p}-334$ ionization. In addition, we suggest that p-334 ionization is a key on energy transfer on-off and that p-334 acts as an energy-converting substance that facilitates cell proliferation. This is a preliminary study and is necessary to acquire a specification of additional information that in the future.

\section{Acknowledgments}

This research was supported by grants from the National Science Council, Taiwan (NSC 99-2313-B-002-023). The 400-MHz NMR facilities used in this study were funded by the NMMBA. We wish to thank Richard P. Cheng, who has provided support for this project.

\section{Author Contributions}

L.-F.C. and H.-N.C. designed the experiment, analyzed the data, and wrote the manuscript. L.-F.C. also performed most of the experiments. P.-J.S. contributed to writing the manuscript.

\section{Conflicts of Interest}

The authors declare no conflict of interest.

\section{References}

1. Sinha, R.P.; Singh, S.P.; Häder, D.P. Database on mycosporines and mycosporine-like amino acids (MAAs) in fungi, cyanobacteria, macroalgae, phytoplankton and animals. J. Photochem. Photobiol. B 2007, 89, 29-35.

2. Hoyer, K.; Karsten, U.; Sawall, T.; Wiencke, C. Photoprotective substances in Antarctic macroalgae and their variation with respect to depth distribution, different tissues and developmental stages. Mar. Ecol. Prog. Ser. 2001, 211, 117-129.

3. Huovinen, P.; Gómez, I.; Figueroa, F.L.; Ulloa, N.; Morales, V.; Lovengreen, C. Ultraviolet-absorbing mycosporine-like amino acids in red macroalgae from Chile. Bot. Mar. 2004, 47, 21-29.

4. Oyamada, C.; Kaneniwa, M.; Ebitani, K.; Murata, M.; Ishihara, K. Mycosporine-like amino acids extracted from scallop (Patinopecten yessoensis) ovaries: UV protection and growth stimulation activities on human cells. Mar. Biotechnol. 2008, 10, 141-150.

5. Tao, C.; Sugawara, T.; Maeda, S.; Wang, X.; Hirata, T. Antioxidative activities of a mycosporine-like amino acid, porphyra-334. Fish. Sci. 2008, 74, 1161-1172.

6. Torres, A.; Enk, C.D.; Hochberg, M.; Srebnik, M. Porphyra-334, a potential natural source for UVA protective sunscreens. Photochem. Photobiol. Sci. 2006, 5, 432-435. 
7. Cardozo, K.H.; Guaratini, T.; Barros, M.P.; Falcão, V.R.; Tonon, A.P.; Lopes, N.P.; Campos, S.; Torres, M.A.; Souza, A.O.; Colepicolo, P.; et al. Metabolites from algae with economical impact. Comp. Biochem. Physiol. C 2007, 146, 60-78.

8. Conde, F.R.; Churio, M.S.; Previtali, C.M. The photoprotector mechanism of mycosporine-like amino acids. Excited state properties and photostability of porphyra-334 in aqueous solution. J. Photochem. Photobiol. B 2000, 56, 139-144.

9. Conde, F.R.; Churio, M.S.; Previtali, C.M. The deactivation pathways of the excited-states of the mycosporine-like amino acids shinorine and porphyra-334 in aqueous solution. Photochem. Photobiol. Sci. 2004, 3, 960-967.

10. Zhang, L.W.; Tashiro, U.; Matsukawa, S.; Ogawa, H. Influence of $\mathrm{pH}$ and temperature on the ultraviolet-absorbing properties of porphyra-334. Fish. Sci. 2005, 71, 1382-1384.

11. Klisch, M.; Richter, P.; Puchta, R.; Hader, D.P.; Bauer, W. The stereostructure of porphyra-334: An experimental and calculational NMR investigation. Evidence for an efficient "proton sponge". Helv. Chim. Acta 2007, 90, 488-511.

12. Kakehashi, R.; Shizuma, M.; Yamamura, S.; Maeda, H. Hydrogen ion titration of alkyldimethylamine oxides by ${ }^{13} \mathrm{C}$ and ${ }^{1} \mathrm{H}$ NMR and conventional methods. J. Colloid Interface Sci. 2005, 289, 498-503.

13. Krężel, A.; Bal, W. A formula for correlating $\mathrm{p} K_{a}$ values determined in $\mathrm{D}_{2} \mathrm{O}$ and $\mathrm{H}_{2} \mathrm{O}$. J. Inorg. Biochem. 2004, 98, 161-166.

14. Weinberg, D.R.; Gagliardi, C.J.; Hull, J.F.; Murphy, C.F.; Kent, C.A.; Westlake, B.C.; Paul, A.; Ess, D.H.; McCafferty, D.G.; Meyer, T.J. Proton-coupled electron transfer. Chem. Rev. 2012, 112, 4016-4093.

15. Cunningham, M.L.; Johnson, J.S.; Giovanazzi, S.M.; Peak, M.J. Photosensitized production of superoxide anion by monochromatic (290-405 nm) ultraviolet irradiation of NADH and NADPH coenzymes. Photochem. Photobiol. 1985, 42, 125-128.

16. Shick, J.M.; Dunlap, W.C. Mycosporine-like amino acids and related gadusols: Biosynthesis, accumulation, and UV-protective functions in aquatic organisms. Annu. Rev. Physiol. 2002, 64, 223-262.

17. Wenthold, P.G.; Squires, R.R. Biradical thermochemistry from collision-induced dissociation threshold energy measurements-Absolute heats of formation of ortho-benzyne, meta-benzyne, and para-benzyne. J. Am. Chem. Soc. 1994, 116, 6401-6412.

18. Blanksby, S.J.; Ellison, G.B. Bond dissociation energies of organic molecules. Acc. Chem. Res. 2003, 36, 255-263.

19. Wenthold, P.G.; Squires, R.R. Gas-phase properties and reactivity of the acetate radical-anion-determination of the $\mathrm{C}-\mathrm{H}$ bond strengths in acetic-acid and acetate ion. J. Am. Chem. Soc. 1994, 116, 11890-11897.

20. Schulten, K.; Tavan, P. A mechanism for the light-driven proton pump of Halobacterium halobium. Nature 1978, 272, 85-86.

21. Kouyama, T.; Kouyama, A.N.; Ikegami, A. Bacteriorhodopsin is a powerful light-driven proton pump. Biophys. J. 1987, 51, 839-841.

22. Tributsch, H. Light driven proton pumps. Ionics 2000, 6, 161-171. 
23. Oren, A. Mycosporine-like amino acids as osmotic solutes in a community of halophilic cyanobacteria. Geomicrobiol. J. 1997, 14, 231-240.

24. Portwich, A.; Garcia-Pichel, F. Ultraviolet and osmotic stresses induce and regulate the synthesis of mycosporines in the cyanobacterium Chlorogloeopsis PCC 6912. Arch. Microbiol. 1999, 172, 187-192.

25. Dunlap, W.C.; Williams, D.McB.; Chalker, B.E.; Banaszak, A.T. Biochemical photoadaptations in vision: UV-absorbing pigments in fish eye tissues. Comp. Biochem. Physiol. B 1989, 93, 601-607.

26. Mason, D.S.; Schafer, F.; Shick, J.M.; Dunlap, W.C. Ultraviolet radiation-absorbing mycosporine-like amino acids (MAAs) are acquired from their diet by medaka fish (Oryzias latipes) but not by SKH-1 hairless mice. Comp. Biochem. Physiol. A 1998, 120, 587-598.

27. Adams, N.L.; Shick, J.M. Mycosporine-like amino acids prevent UVB-induced abnormalities during early development of the green sea urchin Strongylocentrotus droebachiensis. Mar. Biol. 2001, 138, 267-280.

28. Adams, N.L.; Shick, J.M.; Dunlap, W.C. Selective accumulation of mycosporine-like amino acids in ovaries of the green sea urchin Strongylocentrotus droebachiensis is not affected by ultraviolet radiation. Mar. Biol. 2001, 138, 281-294.

29. Karentz, D.; Dunlap, W.C.; Bosch, I. Temporal and spatial occurrence of UV-absorbing mycosporine-like amino acids in tissues of the antarctic sea urchin Sterechinus neumayeri during springtime ozone-depletion. Mar. Biol. 1997, 129, 343-353.

30. Grant, P.T.; Plack, P.A. Gadusol, a metabolite from fish eggs. Tetrahedron Lett. 1980, 21, 4043-4044.

31. Plack, P.A.; Fraser, N.W.; Grant, P.T.; Middleton, C.; Mitchell, A.I.; Thomson, R.H. Gadusol, an enolic derivative of cyclohexane-1,3-dione present in the roes of cod and other marine fish. Isolation, properties and occurrence compared with ascorbic acid. Biochem. J. 1981, 199, 741-747.

32. Volkmann, M.; Gorbushina, A.A. A broadly applicable method for extraction and characterization of mycosporines and mycosporine-like amino acids of terrestrial, marine and freshwater origin. FEMS Microbiol. Lett. 2006, 255, 286-295.

(C) 2014 by the authors; licensee MDPI, Basel, Switzerland. This article is an open access article distributed under the terms and conditions of the Creative Commons Attribution license (http://creativecommons.org/licenses/by/3.0/). 